\title{
Challenges of textile industry in the framework of Circular Economy: case from Latvia
}

\author{
Dzintra Atstāja ${ }^{1,2, *}$, Natālija Cudečka-Puriņa ${ }^{2}$, Rudīte Vesere $^{3}$, Lilita Ābele $^{2}$, and Sergiy \\ Spivakovskyy $^{4}$ \\ ${ }^{1}$ BA School of Business and Finance, $161 \mathrm{Kr}$.Valdemara, Riga, LV-1013, Latvia \\ ${ }^{2}$ University of Liepaja, 14 Liela str., Liepaja, LV-3401, Latvia \\ ${ }^{3}$ Riga Technical university, Kalku iela 1, Centra rajons, Riga, LV-1658, Latvia \\ ${ }^{4}$ Higher Colleges of Technology, PO Box, 25026 Abu Dhabi, United Arab Emirates
}

\begin{abstract}
The Covid-19 pandemic has highlighted such challenges for the world's socio-economic and financial systems Social entrepreneurship is an integral part of Europe's diverse social market economy. The aim of the paper is to tackle the social entrepreneurship field in Latvia and in particular to reveal the enterprises operating in the textile industry, as fashion industry in general is evaluated as second polluting industry, being just behind oil industry. The paper is limited to social entrepreneurship in the field of textile, as it is a new waste stream that has received particular goals and thus needs to be managed in a more sustainable way. To promote social enterprises in the field of textile production and processing it is especially important to implement elements of the circular economy in the daily activities of a social enterprise. Fostering social entrepreneurship in the textile field allows to reach a range of goals simultaneously, including, but not limited to - decrease of textile waste volume, increase of upcycling and moving towards circular economy targets.
\end{abstract}

\section{Introduction}

Climate change policy, based on the Sustainable Development Goals (SDGs), is the inspiration for many types of business that combine value creation with environmental protection and social protection. The thinking and understanding of the participants of economic processes influences how much attention they pay to the circulation potential of the intended circulation business models. The literature [1-2] offers a set of principles to prepare innovation participants for experiments and increase their ability to rethink their life assumptions. Businesses are looking for ways to thrive in a competitive environment with innovative business models while respecting society and avoiding actions that harm the planet. Trends such as the circular economy, fair trade, small numbers, and the shared economy are some of the many new business approaches that address this issue, but there is still a gap between the theoretical arguments and the level of environmental and social sustainability realized in practice [3]. The circular economy could be described as a

\footnotetext{
*Corresponding author: dzintra.atstaja@ba.lv
} 
network of smaller circular economies, where the main development is in local areas, such as cities or regions, with the active involvement of territorial stakeholders. The active role of social entrepreneurs in supporting the transition in the regions and emphasizes the great diversity of challenges they face in developing local business models at technological, social and policy levels [4]. Changes at the societal level and the complexity of socioecological systems call for a holistic approach and foresight in the development of strategies, policies, and programs [2] to turn economic activities into loops for human and environmental care.

Experiments with a circular business model can help companies move to a circular economy [4]. Some studies [5] have developed models based on the factors that determine the quality of the business environment and based on confirmatory factor analysis and modeling of structural equations that show the causal links between the quality of the business environment and its determinants in SMEs. The most important factors determining the quality of the business environment are the macroeconomic environment, monetary policy, interest rates and the legal environment. The results of the research show the need $[1,5-10]$ to reduce the state bureaucracy.

Circular economy systems, methodologies and tools need to strengthen its social dimension. Adequate institutional arrangements and strategic leadership are needed for this paradigm shift to promote sustainable development. Further research is needed to further understand the types of principles that can drive meaningful experiments to the circular economy. Textiles are fundamental to our society, providing us with clothing, shoes, carpets, curtains, furniture, etc. for homes, offices and public buildings.

Textiles are the fourth highest-pressure category for the use of primary raw materials and water, after food, housing and transport, and fifth for GHG emissions [11 - 12].

Overall textile waste in Latvia accounts for approximately 27,000 tons, which accounts for $3-5 \%$ of total household waste generated in the country, or for approximately $14.3 \mathrm{~kg}$ of clothes per capita [13]. Once discarded, only $20 \%$ of clothing waste is collected for re-use and recycling at a global level [14 - 15].

Since 1996, the amount of clothes bought in the EU per person has increased by $40 \%$ following a sharp fall in prices, which has reduced the life span of clothing. Europeans use nearly 26 kilos of textiles and discard about 11 kilos of them every year. Used clothes can be exported outside the EU but are mostly (87\%) incinerated or landfilled. Globally less than $1 \%$ of clothes are recycled as clothing, partly due to inadequate technology [19].

This research is being developed using mainly secondary data analysis and primary data obtained from structured interviews. In addition, the authors use critical data analysis, develop particular case studies and undertake comparative analysis.

\section{Social entrepreneurship in Latvia}

In 2013 the Ministry of Welfare started work on the development of a new policy initiative to promote the development of a legal framework for social entrepreneurship and the integration of disadvantaged people into the labour market. In autumn 2015 the Latvian Social Entrepreneurship Association was founded, the aim of which is to promote the development of social entrepreneurship in Latvia. In order to support development of social enterprises, a financial support mechanism has been launched since 2015. The grants have been developed for the implementation of viable social entrepreneurship projects, for achieving a social goal. Currently it is possible to apply for grants from 5,000 to 200,000 EUR for investments or current assets (incl. remuneration costs). The main requirement is that a business idea must be viable, with a significant long-term social impact. By the end of 2020 in total 97 grants were assigned, with the overall financing of 6.3 million EUR, out 
of which 37 business projects have already been implemented, resulting in 2.3 million EUR [20].

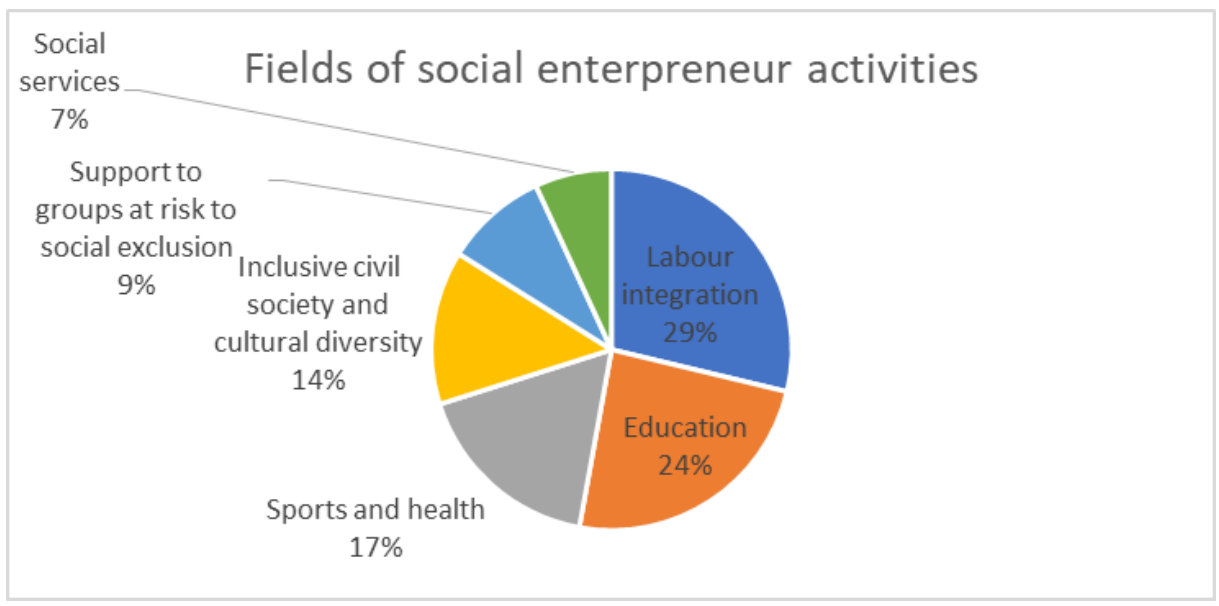

Fig. 1. Fields of social enterprise activities.

A social enterprise is a limited liability company which, in accordance with the procedures laid down in this Law, has been granted the status of a social enterprise and which conducts an economic activity that creates a positive social impact (e. g. provision of social services, formation of an inclusive civil society, promotion of education, support for science, protection and preservation of the environment, animal protection, or ensuring cultural diversity) [21]. Currently, there are a total of 161 active social entrepreneurs and 15 non-active entrepreneurs who are acting in different fields. The percentage distribution of the fields is depicted in the Figure 1.

\section{Discussion}

This paper will analyse all the enterprises that focus on clothing or textile production. In total out of 176 enterprises there are only 4 active enterprises engaged in this field.

Table 2 below provides a short summary of analysed companies.

Table 2. Enterprises chosen for a basis of the case-studies.

\begin{tabular}{|c|c|c|}
\hline Enterprise & NACE code & Main activity \\
\hline OWA & $\begin{array}{c}\text { Manufacture of other knitted } \\
\text { and crocheted apparel }\end{array}$ & $\begin{array}{c}\text { Wholesale of clothing and } \\
\text { footwear }\end{array}$ \\
\hline Mans Peldkostīms & $\begin{array}{c}\text { Manufacture of other apparel } \\
\text { and accessories }\end{array}$ & $\mathrm{n} / \mathrm{a}$ \\
\hline Zīle-Zīle & $\begin{array}{c}\text { Retail sale of clothing in } \\
\text { specialised stores }\end{array}$ & Manufacture of other outerwear \\
\hline Print Art & Manufacture of apparel & $\begin{array}{l}\text { Wholesale of clothing and } \\
\text { footwear }\end{array}$ \\
\hline
\end{tabular}

\subsection{Enterprises chosen for a basis of the case-studies}

\subsubsection{OWA}


OWA - is the first brand in Latvia that offers clothes with watercolour and graphic prints, which are transferred to the fabric with the help of sublimation printing. This technique provides excellent colour fastness and tonal transitions. The laconic design clothing brand OWA is a balance of femininity and functionality. Bright watercolours created by artists Alisa Ādamsone and Vera Bondāre make the clothes unique and easily recognizable. The enterprises strive to combine classic and extravagance, softness and comfort, practicality and reliability [19].

Aim of the enterprise: to promote the employment and integration of the socially vulnerable population, especially the disabled, people of pre-retirement age and young parents; to change stereotypes regarding work ability and productivity of people with disabilities, people of pre-retirement age and young parents; to demonstrate that vulnerable people, especially people with disabilities, are able to compete on an equal footing in business and produce a competitive product [22].

\subsubsection{Mans Peldkostīms - Swimbe}

The enterprise offers custom made swimsuits for women and children, which are produced out of old fishing nets, carpets, PET bottles and other plastic waste. Fabrics are identical in their properties and feel to traditionally obtained fabrics. Such production makes it possible to create high-quality clothing without wasting new resources on the planet [21].

Aim of the enterprise: to undertake social business with the aim of reducing the growth of plastic and textile waste in Latvia and in the world by promoting their recycling into raw materials suitable for clothing production, which the enterprise will use for sewing individual swimwear [23-24].

\subsubsection{Zīle-Zīle}

ZİLE is a Latvian fashion brand striving for a more sustainable future through the concept of upcycling. The label's main resource materials are denim trousers, men's shirts and fantasy. At the core of the brand is the idea that what people wear is a symbol of their character, identity and values, and that the global environmental trend is an important part of current values. That is why ZİLE reimagines and reworks classical garments to create a

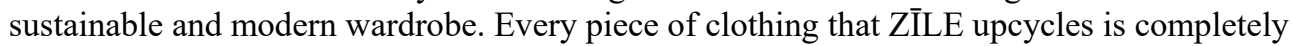
unique. ZĪLE uses second-hand clothing that is either bought in vintage shops or donated by our collaboration partner, charity shop OTRA ELPA [25].

Aim of the enterprise: to reduce the amount of textile waste by creating new valueadded products. Promote awareness of resource reuse [23].

\subsubsection{Print Art}

The idea of creating a T-shirt that helps to improve the posture arose naturally as both authors faced this problem and first created this product for themselves. The existing posture correctors of different producers in general cannot provide the necessary daily support as they are either uncomfortable, they cannot be worn all day long or they are too visible to others. The doctors whom the authors addressed also confirmed that a back needs freedom of movement and close shoulder fixation harms the posture rather than improving it. The only way to improve the posture is through the training of back muscles, and the posture-correcting T-shirt performs this function on a daily basis. The main objective was to create a wearable posture corrector that: is easy to use - no additional adjustments required; is comfortable to wear- it doesn't rub, scratch or cause itching; pleasant to wear 
thanks to the soft material that is similar to cotton; is 'invisible' and can be adapted to any style; improves well-being and increases self-confidence [26].

Aim of the enterprise: to promote the employment and integration of the socially vulnerable, especially the disabled, people of pre-retirement age and young parents; to change stereotypes regarding work ability and productivity of people with disabilities, people of pre-retirement age and young parents; to show that socially-vulnerable people, especially people with disabilities, can compete on an equal footing in business and produce a competitive product [20].

\section{Results}

The authors have conducted a series of structured interviews with representatives from the enterprises mentioned above and have summarised the results. The interviews consisted of 8 open-type questions. All the enterprises interviewed are considered to be small, with employee numbers from 1 to 10 . One enterprise was established in 2015, two others in 2018 and one in 2019. All of them obtained the status of Social entrepreneur and are obliged to renew it on an annual basis by submitting reports and performance indicators. This system of annual status renewal ensures that the enterprises are kept within strict boundaries and cannot just obtain the status for the sake of formality.

Only one of the interviewed stated that the main barriers to obtaining social entrepreneur status have been bureaucracy and a very complicated admission and evaluation procedure. This means that in Latvia's case it was possible to develop a clear and transparent registration scheme, as well as a grant application procedure.

Analysis of Figure 2 shows that the interviewed enterprises are open to a circular economy and are already actively engaging its elements within their business models. Moreover, they are open for a more extensive integration, although certain interviewees highlighted the fact that there is a lack of knowledge of certain circular economy elements and support from the state side in these regards. The enterprises focus on such aspects as recycled packaging, or wherever possible avoiding packaging. The development of byproducts is stimulated by the idea of minimising waste. The enterprises apply certain aspects of industrial symbiosis, i. e. garment upcycling enterprise ZĪLE-ZĪLE receives material which has been donated to a charity shop and which has not been sold, another positive example is resource sharing - offering equipment to other enterprises in order to share the administrative costs and to avoid standstills. A notable aspect in waste prevention - example from OWA - a special jar for needle collection, thus avoiding their entry into the waste stream and potential harm to wildlife. 
Fig. 2. Application of Circular Economy in the business model.

\subsubsection{Influence of Covid-19 pandemic and lockdowns on the business}

It cannot be ignored that the past year has influenced the businesses dramatically. Latvia has come through 2 lockdowns, one in spring 2020 and the other one starting from November 2020, which is still in place until April and it is more likely that afterwards a range of restrictions will still be applied to the economy. This situation has had a dramatic impact on the enterprises analysed within the present research as all of them are small enterprises and some of them involve the vulnerable section of society. The main issues are depicted in Figure 3 below.

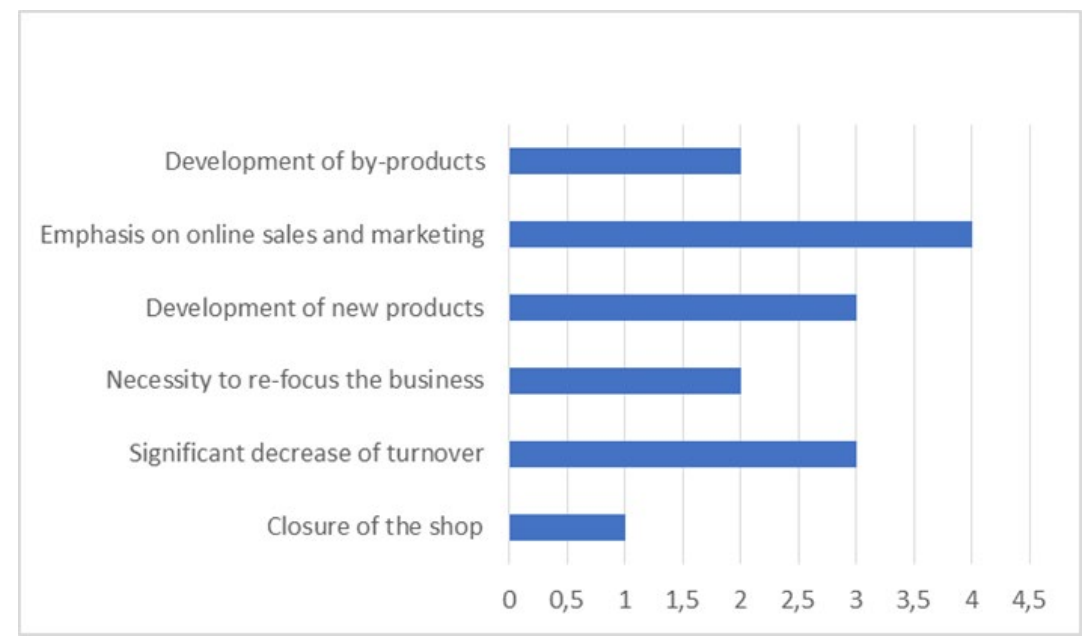

Fig. 3. Influence of Covid-19 pandemic.

It is worth pointing out that Covid-19 has stimulated the enterprises to become more responsible in terms of waste minimisation, leading to maximising the use of textile raw material or to re-use the clippings (offcuts of cloths) - the enterprises either develop certain new products using the clippings or produce limited clothing collections (e. g. for children). 


\subsubsection{Corporate social responsibility and social enterprises}

The interviews revealed that the enterprises are actively implementing Corporate Social Responsibility. Most notable examples of CSR are transparency of the production process; involvement of the customer/end user into the production process; donations to disabled people by designing and producing tailor-made garments.

\section{Conclusions}

The authors would like to highlight a range of conclusions stemming from the literature research undertaken, case-study analysis and interviews. Primarily, when a country or a region wishes to promote social entrepreneurship it is vital to understand the process of validation and to make it as simplistic as possible. It is essential to keep in mind that the social enterprises in most cases are not only established following the famous quote of Milton Friedman "The business of business is business", but in most cases generally they pursue a goal of solving certain social problems.

Therefore, the authors strongly recommend developing a transparent and clear set of rules for an enterprise to be able to apply for social enterprise status, thereby also reducing the bureaucratic burden.

Secondly, it is essential to implement circular economy elements in the daily operations of social enterprise. This is why the authors recommend developing certain guidelines for the enterprises (here the guidelines could start with social enterprises, but afterwards could also be extended to cover all types of enterprises) on circular economy elements and practical aspects on how to shift from linear to more circular business models, by implementing aspects like resource-sharing, equipment-sharing, use of symbiosis when one company's waste might become another's ram/input material, use of recycled and/or recyclable materials both in the production process and in packaging, etc.

Textile waste is a considerably new waste fraction that has been assessed and particular targets have been set by the Directive on waste, this is why the authors consider it extremely important to foster social enterprises in the field of textile production and upcycling. It is necessary to promote wise consumption and stop fast fashion, as well as to promote upcycling activities in order to reduce the volume of textile waste ending up in landfills or in waste to energy plants.

The authors foresee that this paper will be first in the series of papers regarding circular economy and social entrepreneurship. For Latvia and other countries, which have developed circular economy strategies or are considering such, social enterprises are a new type of entrepreneurship, new business models which are fostering the transition to a circular economy, and wiser consumption.

This research was carried out within the project of Latvian Council of Science Nr. lzp-2020/2-0317 «The Impact of COVID-19 on Sustainable Consumption Behaviours and Circular Economy».

\section{References}

1. Crecente, F., Sarabia, M., \& Teresa del Val, M. (2020). Climate change policy and entrepreneurial opportunities. Journal of Cleaner Production, 277. https://doi.org/10.1016/j.techfore.2020.120446

2. Pla-Julián, I., \& Guevara, S. (2019). Is circular economy the key to transitioning towards sustainable development? Challenges from the perspective of care ethics. Futures, 105, 67-77. 
3. Todeschini, B.V., Cortimiglia, M.N., Callegaro-de-Menezes, D., \& Ghezzi, A. (2017). Innovative and sustainable business models in the fashion industry: Entrepreneurial drivers, opportunities, and challenges. Business Horizons, 60(6), 759-770. https://doi.org/10.1016/j.bushor.2017.07.003

4. Konietzko, J., Baldassarre, B., Brown, P., Bocken, N., \& Hultink, E.J. (2020). Circular business model experimentation: Demystifying assumptions. Journal of cleaner production. 277. https://doi.org/10.1016/j.jclepro.2020.122596

5. Belas, J., Dvorsky, J., Strnad, Z., Valaskova, K., \& Cera, G. (2019). Improvement of the quality of business environment model: Case of the SME segment. Inzinerine ekonomika-engineering economics, 30(5), 601-611. https://doi.org/10.5755/j01.ee.30.5.24490

6. Real, M., Lizarralde, I., \& Tyl, B. (2019). Exploring Local Business Model Development for Regional Circular Textile Transition in France. Fashion practice-the journal of design creative process \& the fashion industry, 12(1), 6-33. https://doi.org/10.1080/17569370.2020.1716546

7. Staicu, D., \& Pop, O. (2018). Mapping the interactions between the stakeholders of the circular economy ecosystem applied to the textile and apparel sector in Romania. Journal of Cleaner Production, 188, 20-37.

8. Beuve, J., Brousseau, E., \& Sgard, J. (2021). Why Are Modern Bureaucracies Special? State Support to Private Firms in Early Eighteenth-Century France. The Journal of Economic History, Cambridge University Press, 77(4), 1144-1176.

9. Veleva, V., \& Bodkin, G. (2017). Corporate-entrepreneur collaborations to advance a circular economy. Business Horizons, 60(6), 759-770.

10. Real, M., Lizzarralde, I., \& Tul, B. (2020). Creative process \& the fashion industry. Fashion practice-the journal of design, 12(1), 6-33. https://doi.org/10.1080/17569370.2020.1716546

11. European Environment Agency. (2019). Textiles in Europe's circular economy. Publications Office. https://doi.org/10.2800/904911

12. European Commission. (2020). A new Circular Economy Action Plan. For a cleaner and more competitive Europe. https://eur-lex.europa.eu/legalcontent/EN/TXT/?qid=1583933814386\&uri=COM:2020:98:FIN

13. Waste statistical overview. (2020). https://www.meteo.lv

14. Koszewska, M. (2018). Circular economy-Challenges for the textile and clothing industry. AUTEX Research Journal, 4, 337-47. https://doi.org/10.1515/aut-2018-0023

15. Beasley, J., \& Georgeson, R. (2014). Advancing resource efficiency in Europe. Indicators andwaste policy scenarios to deliver a resource efficient and sustainable Europe, Brussels:European Environmental Bureau (EEB).

16. Mikhno, I., Koval, V., Shvets, G., Garmatiuk, O., \& Tamošiūnienè, R. (2021). Green Economy in Sustainable Development and Improvement of Resource Efficiency. Central European Business Review, 10(1), 99-113. https://doi.org/10.18267/j.cebr.252

17. Dankeieva, O., Solomianiuk, N., Strashynska, L., Fiedotova, N., Soloviova, Y., \& Koval, V. (2021). Application of Cognitive Modelling for Operation Improvement of Retail Chain Management System. TEM Journal, 10(1), 358-367. https://doi.org/10.18421/TEM101-45

18. Koval, V., Mikhno, I., Trokhymets, O., Kustrich, L., Vdovenko, N. (2020). Modeling the interaction between environment and the economy considering the impact on $\begin{array}{lllll}\text { ecosystem. E3S Web } & 13002 .\end{array}$ https://doi.org/10.1051/e3sconf/202016613002 
19. European Parliament (2020). The impact of textile production and waste on the environment.

https://www.europarl.europa.eu/news/en/headlines/society/20201208STO93327

20. Altum (2020). Social entrepreneurship. https://www.altum.lv/lv/pakalpojumi

21. Law on social enterprise. (2017). https://likumi.lv/ta/en/en/id/294484-social-enterpriselaw

22. OWA (2021). About the enterprise. https://www.owa.lv/parowa

23. Ministry of Welfare of Republic of Latvia (2021). Social enterprise registry. https://www.lm.gov.lv/lv/socialo-uznemumu-registrs

24. Swimbe (2021). About the enterprise. http://www.swimbe.lv/par-mums

25. ZĪLE-ZĪLE (2021). About the enterprise. https://zile-zile.com/pages/about

26. Correcty (2021). About the enterprise. https://correcty.eu/about-us 